\title{
Estimation of creatinine clearance using plasma creatinine or cystatin C: a secondary analysis of two pharmacokinetic studies in surgical ICU patients
}

Thomas Steinke ${ }^{1}$, Stefan Moritz ${ }^{1}$, Stefanie Beck², Carsten Gnewuch ${ }^{3}$ and Martin G Kees ${ }^{4,5^{*}}$

\begin{abstract}
Background: In ICU patients, glomerular filtration is often impaired, but also supraphysiological values are observed ("augmented renal clearance", $>130 \mathrm{~mL} / \mathrm{min} / 1.73 \mathrm{~m}^{2}$ ). Renally eliminated drugs (e.g. many antibiotics) must be adjusted accordingly, which requires a quantitative measure of renal function throughout all the range of clinically encountered values. Estimation from plasma creatinine is standard, but cystatin C may be a valuable alternative.

Methods: This was a secondary analysis of renal function parameters in 100 ICU patients from two pharmacokinetic studies on vancomycin and betalactam antibiotics. Estimated clearance values obtained by the Cockcroft-Gault


measured endogenous creatinine clearance $\left(\mathrm{CL}_{\mathrm{CR}}\right)$. Agreement of values was assessed by modified Bland-Altman plots and by calculating bias (median error) and precision (median absolute error). Sensitivity and specificity of estimates to identify patients with reduced ( $<60 \mathrm{~mL} / \mathrm{min} / 1.73 \mathrm{~m}^{2}$ ) or augmented $\left(>130 \mathrm{~mL} / \mathrm{min} / 1.73 \mathrm{~m}^{2}\right) \mathrm{CL}_{\mathrm{CR}}$ were calculated.

Results: The $\mathrm{CL}_{\mathrm{CR}}$ was well distributed from highly compromised to supraphysiological values (median 73.2, range $16.8-234 \mathrm{~mL} / \mathrm{min} / 1.73 \mathrm{~m}^{2}$ ), even when plasma creatinine was not elevated $(\leq 0.8 \mathrm{mg} / \mathrm{dL}$ for women, $\leq 1.1 \mathrm{mg} / \mathrm{dL}$ for men). Bias and precision were $+13.5 \mathrm{~mL} / \mathrm{min} / 1.73 \mathrm{~m}^{2}$ and $\pm 18.5 \mathrm{~mL} / \mathrm{min} / 1.73 \mathrm{~m}^{2}$ for $\mathrm{eCL}_{\mathrm{CG}}$, 7.59 and $\pm 16.8 \mathrm{~mL} / \mathrm{min} /$ $1.73 \mathrm{~m}^{2}$ for eCL $\mathrm{CKD}_{\text {-EPl, }}$ and -4.15 and $\pm 12.9 \mathrm{~mL} / \mathrm{min} / 1.73 \mathrm{~m}^{2}$ for $\mathrm{eCL}_{\text {Hoek, }}$ respectively, with $\mathrm{eC} \mathrm{L}_{\text {Hoek }}$ being more precise than the other two $(p<0.05)$. The central $95 \%$ of observed errors fell between -59.8 and $+250 \mathrm{~mL} / \mathrm{min} / 1.73 \mathrm{~m}^{2}$ for $\mathrm{eCL}_{\mathrm{CG},}-83.9$ and $+79.8 \mathrm{~mL} / \mathrm{min} / 1.73 \mathrm{~m}^{2}$ for $\mathrm{eCL}_{\mathrm{CKD} \text {-EPl, }}$ and -103 and $+27.9 \mathrm{~mL} / \mathrm{min} / 1.73 \mathrm{~m}^{2}$ for eCL $\mathrm{L}_{\text {Hoek }}$. Augmented renal clearance was underestimated by $\mathrm{CC}_{\mathrm{CKD}-\mathrm{EPI}}$ and $\mathrm{eC}_{\text {Hoek. }}$. Patients with reduced $\mathrm{CL}_{\mathrm{CR}}$ were identified with good specificity by eCL $L_{C G}, e C L_{C K D-E P I}$ and eCL Hoek $(0.95,0.97$ and 0.91 , respectively), but with less sensitivity $(0.55,0.55$ and 0.83$)$. For augmented renal clearance, specificity was $0.81,0.96$ and 0.96 , but sensitivity only $0.69,0.25$ and 0.38 .
\end{abstract}

Conclusions: Normal plasma creatinine concentrations can be highly misleading in ICU patients. Agreement of the cystatin $\mathrm{C}$ based $\mathrm{eC}_{\text {Hoek }}$ with $\mathrm{CL}_{\mathrm{CR}}$ is better than that of the creatinine based $\mathrm{eCL}_{\mathrm{CG}}$ or $\mathrm{eCL}_{\mathrm{CKD} \text {-EPI. }}$. Detection and quantification of augmented renal clearance by estimates is problematic, and should rather rely on $\mathrm{CL}_{\mathrm{CR}}$.

Keywords: Pharmacokinetics, Drug dosing, Glomerular filtration

\footnotetext{
*Correspondence: martin.kees@charite.de

${ }^{4}$ Department of Anesthesiology and Intensive Care, Charité

Universitätsmedizin Berlin - Campus Benjamin Franklin, Hindenburgdamm

30, 12200 Berlin, Germany

${ }^{5}$ Department of Clinical Pharmacy and Biochemistry, Institute of Pharmacy,

Freie Universitaet Berlin, Kelchstr. 31, 12169 Berlin, Germany

Full list of author information is available at the end of the article
} 


\section{Background}

In critical care, renal function receives much attention because deteriorations are frequently part of syndromes such as sepsis or low-output, and often associated with a dire prognosis [1]. Early recognition may offer the chance of successful treatment and hopefully prevention of progression to renal failure. For this purpose, the diagnostic approach must be able to discriminate normal from abnormal renal function, and to differentiate the latter into a limited number of degrees of severity. Despite all its drawbacks, plasma creatinine is still recommended as the primary biomarker for the evolution of acute kidney injury [1]. Since plasma creatinine (and other markers) can only start to rise when renal function is already compromised, research is rather directed towards identification and validation of markers of the preceding tissue damage, e.g. of cell cycle arrest [2,3].

A separate issue is the necessity to adjust the dose of drugs with predominantly renal elimination to renal function. Many antibiotics, e.g. aminoglycosides, glycopeptides, betalactams and part of the fluoroquinolones, fall into this category. Recommendations by the manufacturers usually suggest a similar approach, with one dosing regimen for patients with "normal“ renal function, and two or three adjusted dosing regimens for patients with reduced creatinine clearance, often starting in the range of $<50-80 \mathrm{ml} / \mathrm{min}$. It is clear that patients with "normal“ renal function will thus exhibit a high variability of actual antibiotic exposure.

In the ICU, three factors make this approach particularly problematic. First, infections are likely to be more severe and rather caused by less susceptible pathogens [4]. The risk of underdosing is therefore more substantial than in less severe cases. Second, some patients without signs of renal impairment will actually not just have a "normal“, but a supraphysiological creatinine clearance $\left(>130 \mathrm{ml} / \mathrm{min} / 1.73 \mathrm{~m}^{2}\right)$. The term „augmented renal clearance" has been coined for this phenomenon few years ago [5], and its prevalence in ICU patients without evidence of kidney injury was recently reported to be up to $65 \%$ in the first week of treatment [6]. Third, creatinine clearance is particularly difficult to estimate in ICU patients. Estimations based on plasma creatinine rely on the assumptions that the endogenous production of creatinine is stable and can be predicted reasonably well from patient characteristics (e.g. age, body weight and sex for the Cockcroft-Gault formula [7]). These assumptions are certainly questionable in ICU patients, and important discrepancies have been shown between the available estimation formulae [8-10]. Particularly, plasma creatinine concentrations within the normal range have been shown to reflect creatinine clearances both considerably below and above the normal range $[6,11]$.
Cystatin $\mathrm{C}$ is an alternative endogenous marker, which is produced in a fairly constant rate by all nucleated cells and subject to glomerular filtration only [12]. Albeit promising and already implemented into clinical guidelines for chronic kidney disease [13], the value of the latter in ICU patients is still uncertain. In the present analysis, we compare the agreement of the estimated clearance of the Cockcroft-Gault formula, the CKD-EPI formula (both based on plasma creatinine), and the Hoek formula based on plasma cystatin $C$ with the measured endogenous creatinine clearance $[7,14,15]$, as well as their respective ability to detect patients with reduced or augmented endogenous creatinine clearance.

\section{Methods}

\section{Study design}

All data presented in this analysis were obtained during two pharmacokinetic studies on vancomycin (study 1 [16]) and piperacillin/tazobactam, meropenem or ceftazidime (study 2; partly published in abstract form [17], manuscript in preparation), respectively, which were conducted at the surgical ICU of the Charité Universitätsmedizin Berlin Campus Benjamin Franklin (study 1 and 2) and two surgical ICUs of the Hospital of the University of Halle (study 2). The study protocols were approved by the competent ethics committees (Berlin: EA4/113/07, EA4/029/11; Halle: 2012-95). Written informed consent for study participation and publication of anonymised clinical data was obtained from the patient or a legal representative. Adult patients who were treated with one of the study drugs and were not on renal replacement therapy were eligible for enrolment. Besides that, no specific criteria of exclusion (e.g. diuresis or plasma creatinine concentration) were applied.

The investigations took place when clinical conditions with regard to hemodynamics and renal function (in terms of vasopressor doses, fluid balance and diuresis) were considered to be stable. Although no exact limits were defined, patients who required a specific clinical assessment (e.g. fluid challenge), further diagnostics or a change of therapy (e.g. starting or stopping a vasopressor or diuretic) were considered to be unstable.

In study 1 (25 patients), urine was collected for 18 hours. During urine collection, four plasma concentrations of creatinine (every 6 hours) and two plasma concentrations of cystatin $C$ (at the beginning and the end) were obtained. The mean values were used for calculations. In study 2, the sampling period was chosen as convenient, and plasma creatinine and cystatin $\mathrm{C}$ were determined in one sample during or at the end of the urine collection interval.

\section{Assessment of renal function}

Plasma and urine creatinine were determined by a standardised enzymatic assay on an ADVIA 1800 chemistry system (ECRE_2; Siemens Healthcare Diagnostics, 
Eschborn, Germany). Plasma cystatin $C$ was determined by a particle-enhanced immunonephelometric assay on a BN II system (N CYSC; Siemens Healthcare Diagnostics, Eschborn, Germany).

Renal function parameters were calculated according to the following formulae as values normalised to body surface area $\left(\mathrm{mL} / \mathrm{min} / 1.73 \mathrm{~m}^{2}\right)$ :

- Measured endogenous creatinine clearance (normalised to $1.73 \mathrm{~m}^{2}$ body surface area):

${ }^{\circ} \mathrm{CL}_{\mathrm{CR}}=$ (urine volume $\times$ urine creatinine)/(collection time $\mathrm{x}$ plasma creatinine)/BSA $\times 1.73$

- According to Cockcroft-Gault [7] (normalised to 1.73 $\mathrm{m}^{2}$ body surface area):

${ }^{\circ} \mathrm{eCL}_{\mathrm{CG}}=(140-$ age $\mathrm{x}$ weight $) /(72 \mathrm{x}$ plasma creatinine)/BSA $\times 1.73 \times 0.85$ for women

- According to the CKD-EPI formula [14]:

${ }^{\circ} \mathrm{eCL}_{\text {CKD-EPI }}=141 \times \min (\text { plasma creatinine } / \mathrm{\kappa}, 1)^{\alpha} \times$ $\max (\text { plasma creatinine } / \kappa, 1)^{-1.209} \times 0.993^{\mathrm{age}} \times 1.018$ (for women)

${ }^{\circ} \mathrm{K}=0.7$ for women, 0.9 for men; $\alpha=-0.329$ for women, -0.411 for men

- According to the Hoek formula [15]:

${ }^{\circ} \mathrm{eCL}_{\text {Hoek }}=(80.35 /$ plasma cystatin $\mathrm{C}-4.32)$

${ }^{\circ}$ Body surface area [18]:

${ }^{\circ}$ BSA $=0.007184 \times$ height $^{0.725} \times$ weight $^{0.425}$

Units: plasma and urine creatinine in $\mathrm{mg} / \mathrm{dL}$, plasma cystatin $\mathrm{C}$ in $\mathrm{mg} / \mathrm{L}$, age in years, (total body) weight in $\mathrm{kg}, \mathrm{BSA}$ in $\mathrm{m}^{2}$, height in $\mathrm{cm}$.

\section{Statistical analysis}

Microsoft Excel for Mac 2011 (Microsoft Corporation, Redmond, WA) was used for calculation of renal function parameters, GraphPad Prism version 6 for MacOSX (GraphPad Software, La Jolla, CA) was used for statistical calculations. For each estimate of clearance $\mathrm{eCL}_{\mathrm{X}}$, a modified Bland-Altman plot $\left(\mathrm{eCL}_{\mathrm{X}}-\mathrm{CL}_{\mathrm{CR}}\right.$ vs. $\left.\mathrm{CL}_{\mathrm{CR}}\right)$ was generated. (Whereas in a classical Bland-Altman plot the $\mathrm{x}$-axis shows the mean value of the compared methods, $\mathrm{CL}_{\mathrm{CR}}$ was preferred here so that individual patients could be identified throughout the three plots by the identical $\mathrm{x}$-value; statistical calculations are not affected by this modification). Bias was defined as the median error $\left(e \mathrm{eL}_{\mathrm{X}}-\mathrm{CL}_{\mathrm{CR}}\right)$, and precision as the median absolute error $\left(\left|e C L_{X}-C_{C R}\right|\right)$. The paired Wilcoxon test was used to test for differences between the absolute errors of the three estimates. Sensitivity and specificity to detect $\mathrm{CL}_{\mathrm{CR}}$-values of $<60$ or $>130 \mathrm{~mL} / \mathrm{min} / 1.73 \mathrm{~m}^{2}$ were calculated for the identical thresholds $\quad<60$ or $>130 \mathrm{~mL} / \mathrm{min} / 1.73 \mathrm{~m}^{2}$ ), and compared by Fisher's exact test. Receiver-operator characteristic curves (ROC) were generated. All p-values provided are two-tailed.

\section{Results}

In total, 100 patients contributed data to this analysis (25 from study 1 and 75 from study 2). Patient characteristics are summarised in Table 1, the full data set is available as Additional file 1. The majority of patients had undergone previous surgery (82 patients; mostly general surgery or neurosurgery), and were receiving the study antibiotics for intraabdominal infections (16 patients), nosocomial meningitis (11), nosocomial pneumonia (46) or other indications (27). Fourty patients received one or more vasopressors, and 61 were on mechanical ventilation on the day of the study. In study 1 , in which 4 creatinine concentrations were determined during the 18 hours collection period, the median relative change between the first and the last value was $\pm 4 \%$. In one patient, it was $-40 \%$ (a decline from 0.55 to $0.33 \mathrm{mg} / \mathrm{dL}$ ), and less than $\pm 18 \%$ in all others. In study 2, in which the duration of urine collection was not standardised, the median collection interval was 12 hours (range 1.92-22.75 hours), and at least $160 \mathrm{ml}$ of urine were obtained. The patients' renal function was spread over a wide range $\left(\mathrm{CL}_{\mathrm{CR}} 16.8-234 \mathrm{~mL} / \mathrm{min} / 1.73 \mathrm{~m}^{2}\right)$, particularly at plasma creatinine concentrations below the upper reference limit, i.e. 0.8 and $1.1 \mathrm{mg} / \mathrm{dL}$ for women and men, respectively (Figure 1). In 42 patients $\mathrm{CL}_{\mathrm{CR}}$ was $<60 \mathrm{~mL} / \mathrm{min} / 1.73 \mathrm{~m}^{2}$, and 16 patients presented augmented renal clearance $\left(\mathrm{CL}_{\mathrm{CR}}>130 \mathrm{~mL} / \mathrm{min} / 1.73 \mathrm{~m}^{2}\right)$. In patients who had suffered a polytrauma, an isolated traumatic brain injury or a subarachnoid hemorrhage (conditions associated with augmented renal clearance) $\mathrm{CL}_{\mathrm{CR}}$ was higher (median $102 \mathrm{~mL} / \mathrm{min} / 1.73 \mathrm{~m}^{2}$ ), and in 5 cases $>130 \mathrm{~mL} / \mathrm{min} / 1.73 \mathrm{~m}^{2}$.

The Bland-Altman plots are shown in Figure 2. Bias of $\mathrm{eCL}_{\mathrm{CG}}$ was $+13.5 \mathrm{~mL} / \mathrm{min} / 1.73 \mathrm{~m}^{2}$ and precision \pm 18.5 $\mathrm{mL} / \mathrm{min} / 1.73 \mathrm{~m}^{2}$, but excessive overestimations were frequent, with the central $95 \%$ of observed errors falling between -59.8 and $+250 \mathrm{~mL} / \mathrm{min} / 1.73 \mathrm{~m}^{2}$. No trend was apparent throughout the range of observed values (Figure 2A). For $\mathrm{eCL}_{\mathrm{CKD} \text {-EPI }}$, bias was $+7.59 \mathrm{~mL} / \mathrm{min} /$ $1.73 \mathrm{~m}^{2}$ and precision $\pm 16.8 \mathrm{~mL} / \mathrm{min} / 1.73 \mathrm{~m}^{2}$ (central 95\%: $\left.-83.9-+79.8 \mathrm{~mL} / \mathrm{min} / 1.73 \mathrm{~m}^{2}\right)$. High values of $\mathrm{CL}_{\mathrm{CR}}$ were underestimated (Figure $2 \mathrm{~B}$ ). The same was true for $\mathrm{eCL}_{\text {Hoek }}$, for which bias and precision were numerically lowest $\left(-4.15\right.$ and $\pm 12.9 \mathrm{~mL} / \mathrm{min} / 1.73 \mathrm{~m}^{2}$, respectively; central 95\%: $-103-+27.9 \mathrm{~mL} / \mathrm{min} /$ $1.73 \mathrm{~m}^{2}$; Figure $2 \mathrm{C}$ ). Absolute errors of $\mathrm{eCL}_{\mathrm{CG}}$ and $\mathrm{eCL}_{\text {CKD-EPI }}$ were not statistically different, but both were different from that of eCL $\mathrm{e}_{\text {Hoek }}(\mathrm{p}<0.05)$.

The sensitivity to detect low values of $\mathrm{CL}_{\mathrm{CR}}$ $\left(<60 \mathrm{~mL} / \mathrm{min} / 1.73 \mathrm{~m}^{2}\right)$ was identically low for $\mathrm{eCL}_{\mathrm{CG}}$ and $\mathrm{eCL}_{\mathrm{CKD} \text {-EPI}}$, and significantly better $(\mathrm{p}<0.01)$ for 
Table 1 Patient characteristics ( $n=100 ; 61$ male, 39 female)

\begin{tabular}{|c|c|c|c|}
\hline & Median & $\begin{array}{l}\text { Interquartile } \\
\text { range }\end{array}$ & Range \\
\hline Age (years) & 66 & $57-74$ & $21-85$ \\
\hline Total body weight (kg) & 78 & $70-90$ & $42-125$ \\
\hline Body height (cm) & 170 & $165-175$ & $138-190$ \\
\hline $\mathrm{BMI}\left(\mathrm{kg} / \mathrm{m}^{2}\right)$ & 26.2 & $23.1-30.3$ & $16.0-41.5$ \\
\hline Length of hospitalisation (days) & 16 & $10-27$ & $2-95$ \\
\hline Creatinine (mg/dL) & 0.75 & $0.50-1.20$ & $0.15-2.83$ \\
\hline Cystatin C (mg/L) & 1.12 & $0.76-1.73$ & $0.50-4.21$ \\
\hline $\mathrm{CL}_{\mathrm{CR}}\left(\mathrm{mL} / \mathrm{min} / 1.73 \mathrm{~m}^{2}\right)$ & 73.2 & 46.8-107 & $16.8-234$ \\
\hline $\mathrm{eCL}_{\mathrm{CG}}\left(\mathrm{mL} / \mathrm{min} / 1.73 \mathrm{~m}^{2}\right)$ & 85.2 & $58.7-137$ & $22.4-462$ \\
\hline $\mathrm{eCL}_{\text {CKD-EPI }}\left(\mathrm{mL} / \mathrm{min} / 1.73 \mathrm{~m}^{2}\right)$ & 87.2 & $59.4-108$ & 16.7-196 \\
\hline $\mathrm{eCL}_{\text {Hoek }}\left(\mathrm{mL} / \mathrm{min} / 1.73 \mathrm{~m}^{2}\right)$ & 67.3 & $42.2-101$ & $14.8-156$ \\
\hline APACHE $\|$ & 18 & $13-23$ & $5-33$ \\
\hline SOFA & 6 & $3-8$ & $0-19$ \\
\hline
\end{tabular}

$\mathrm{CL}_{\mathrm{CR}}$ : measured endogenous creatinine clearance; $\mathrm{eCL}_{\mathrm{CG}}$, eCL $\mathrm{CLD}_{\mathrm{CEP}}, \mathrm{eCL}_{\text {Hoek}}$ : estimated clearance by the Cockcroft-Gault, CKD-EPI or Hoek formula; APACHE II: acute physiology and chronic health evaluation II score. SOFA: sequential organ failure assessment score.
$\mathrm{eCL}_{\text {Hoek }}$. Specificity was $>0.9$ for all three estimates. Patients with augmented renal clearance $(>130 \mathrm{~mL} /$ $\min / 1.73 \mathrm{~m}^{2}$ ) were identified with the highest sensitivity by $\mathrm{eCL}_{\mathrm{CG}}$, but specificity was significantly lower than that of the other two $(\mathrm{p}<0.01$; Table 2$)$. The ROC curves both for low and high $\mathrm{CL}_{\mathrm{CR}}$ showed a slightly higher discriminative power (in terms of AUC) for $\mathrm{eCL}_{\mathrm{Hoek}}$ than for $\mathrm{eCL}_{\mathrm{CG}}$ and $\mathrm{eCL}_{\mathrm{CKD} \text {-EPI }}$ (Figure 3).

Since the variable duration of urine collection could have influenced the results, subsets were reanalysed which included only the patients of study $1(n=25)$, or all patients in which urine was collected for at least 12 hours $(n=66)$ or less than 8 hours $(n=31)$. The results did not show any relevant differences compared to the complete data set (Additional file 2).

\section{Discussion}

With the present study, we provide data on the agreement of estimates of renal function based on plasma creatinine or cystatin $\mathrm{C}$ with measured endogenous creatinine clearance in ICU patients. In accordance with other studies $[6,11]$, we observed extreme values of measured endogenous creatinine clearance in patients with plasma creatinine concentrations below the upper reference limit $(\leq 0.8 \mathrm{mg} /$ $\mathrm{dL}$ for women, $\leq 1.1 \mathrm{mg} / \mathrm{dL}$ for men), clearly illustrating the

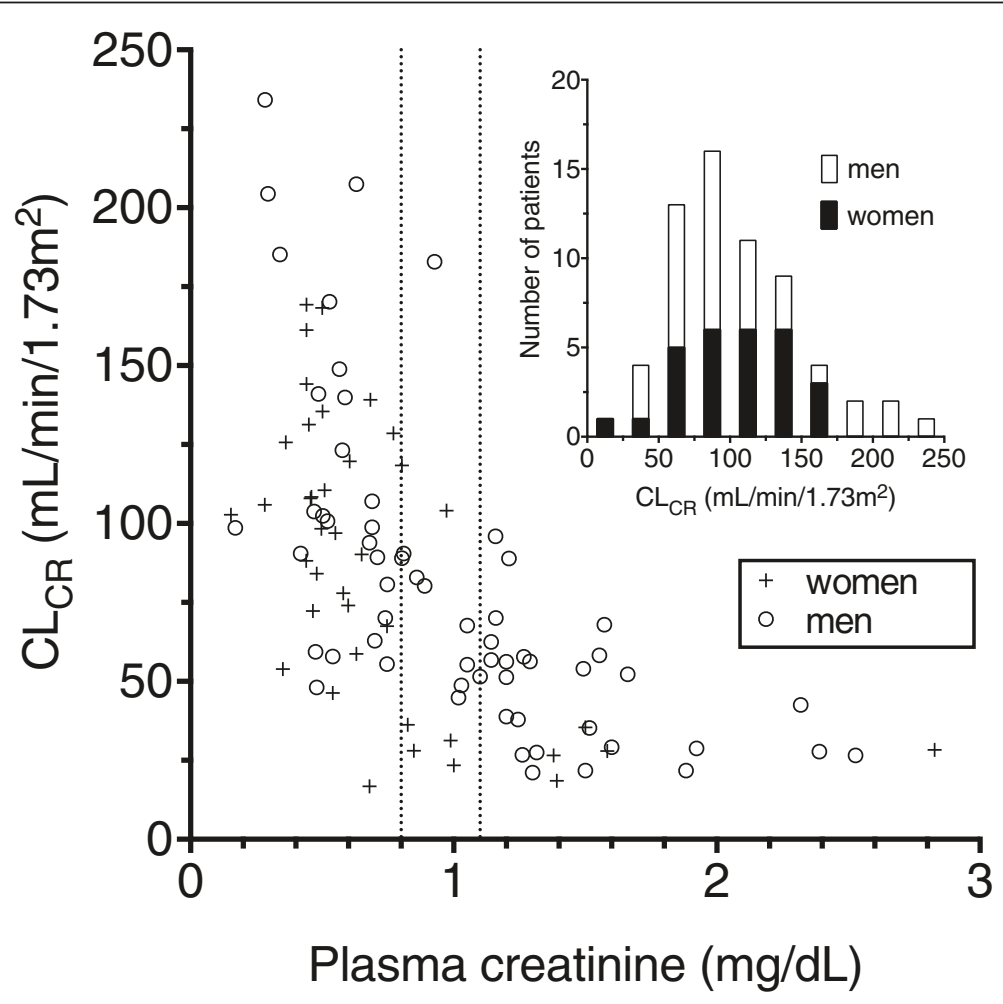

Figure 1 Measured creatinine clearance $\left(\mathrm{CL}_{C R}\right)$ vs. plasma creatinine. Data were obtained from $100 \mathrm{ICU}$ patients participating in pharmacokinetic studies on antibiotics. The inlet shows the distribution of the 63 patients with a plasma creatinine concentration below the upper reference limit (0.8 mg/dL for women, $1.1 \mathrm{mg} / \mathrm{dL}$ for men; vertical dotted lines). 

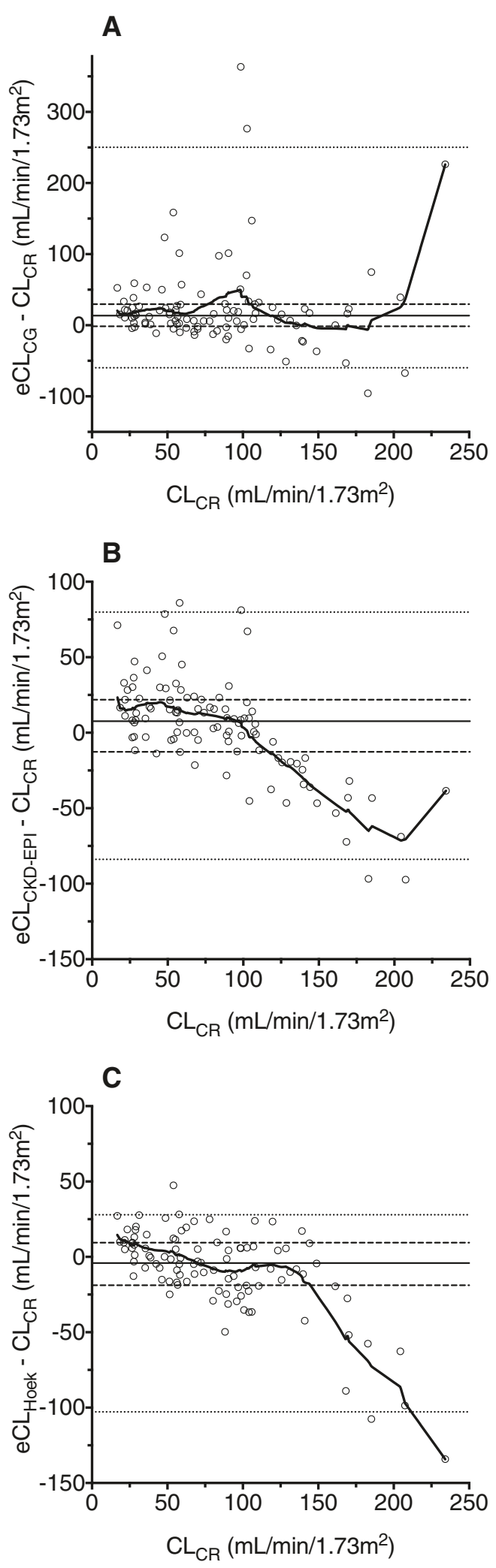

Figure 2 Agreement of estimated with measured creatinine clearance $\left(\mathrm{CL}_{C_{R}}\right)$ in $100 \mathrm{ICU}$ patients. Estimation was done by $(\mathbf{A})$ the Cockcroft-Gault formula (eCL $\left.L_{C G}\right)$, (B) the CKD-EPI formula (eCL $L_{C K D-E P I)}$, or (C) the Hoek formula (eCL $L_{\text {Hoek }}$ ). Bold line: LOWESS curve. Horizontal solid line: median; dashed lines: 25th/75th percentile; dotted lines: $2.5 \mathrm{th} /$ 97.5th percentile of observations. Note the larger scale of the $y$-axis in figure $\mathrm{A}$.

need for a more reliable quantification of renal function in this population.

Although the bias of all three estimates appeared acceptable, it is obvious that their precision is limited and may be completely misleading with regard to the actual renal function. Both creatinine based estimates tended to overestimate low or normal $\mathrm{CL}_{\mathrm{CR} \text {-values, which was }}$ also reflected by a low sensitivity to detect patients with reduced renal function. In this range, the cystatin $\mathrm{C}$ based Hoek formula was significantly more precise, and notably more sensitive with similar specificity. A plausible explanation for this is that cystatin $\mathrm{C}$ does not depend on muscle mass, unlike creatinine. All three formulae were derived from non-critically ill populations, and imply certain relationships between measures of body size (weight or BSA) and the production of cystatin $\mathrm{C}$ or creatinine. Loss of muscle mass due to immobilisation and catabolism is certainly a prominent feature in many critically ill patients, and necessarily affects the accuracy of creatinine based estimates. Cystatin C might therefore offer an advantage for assessing renal function both in clinical routine and research, when a timed urine collection or the clearance of an exogenous marker is not available. However, its exact significance must be further explored and defined, also to justify the much higher costs (in our institution ca. $10 €$ per determination compared with $0.50 €$ for creatinine). Although there are several reports on cystatin C-guided therapy with vancomycin or aminoglycosides [19-22], such informations are generally lacking for most drugs. Further open issues are the availability of standardised commercial assays, and confounding effects of various disease states. In contrast to initial reports, the production of cystatin $C$ is not entirely constant either [12,23]. In the context of critical care, particularly inflammation, glucocorticoids and dysthyroid states could influence its levels, but also preexisting conditions such as obesity and smoking. Unfortunately, these confounding conditions were not assessed in our study, but given their rather generic nature it appears safe to assume that many patients with one or more of these conditions were represented in the study.

Baptista and colleagues made similar observations in 54 critically ill patients [9]. Although patients with plasma creatinine $>1.3 \mathrm{mg} / \mathrm{dL}$ were excluded, $8 \mathrm{~h}-\mathrm{CL}_{\mathrm{CR}}$ ranged from 16.2 to $378.3 \mathrm{~mL} / \mathrm{min} / 1.73 \mathrm{~m}^{2}$, and the Cockcroft-Gault, the MDRD and the CKD-EPI formulae 
Table 2 Sensitivity and specificity ( $95 \%$ confidence intervals) to detect reduced or augmented endogenous creatinine clearance

\begin{tabular}{|c|c|c|c|c|}
\hline & \multicolumn{2}{|c|}{$\mathrm{CL}_{\mathrm{CR}}<60 \mathrm{~mL} / \mathrm{min} / 1.73 \mathrm{~m}^{2}$} & \multicolumn{2}{|c|}{$\mathrm{CL}_{\mathrm{CR}}>130 \mathrm{~mL} / \mathrm{min} / 1.73 \mathrm{~m}^{2}$} \\
\hline & sensitivity & specificity & sensitivity & specificity \\
\hline$\overline{\mathrm{eCL}}$ & $0.55(0.39-0.70)$ & $\begin{array}{l}0.95 \\
(0.86-0.99)\end{array}$ & $\begin{array}{l}0.69 \\
(0.41-0.89)^{* *}\end{array}$ & $\begin{array}{l}0.81 \\
(0.71-0.89)^{* * *}\end{array}$ \\
\hline$e C L_{C K D-E P I}$ & $0.55(0.39-0.70)$ & $\begin{array}{l}0.97 \\
(0.88-1.0)\end{array}$ & $\begin{array}{l}0.25 \\
(0.073-0.52)\end{array}$ & $0.96(0.90-0.99)$ \\
\hline eCL Hoek & $0.83(0.69-0.93)^{*}$ & $\begin{array}{l}0.91 \\
(0.81-0.97)\end{array}$ & $\begin{array}{l}0.38 \\
(0.15-0.65)\end{array}$ & $0.96(0.90-0.99)$ \\
\hline
\end{tabular}

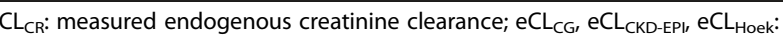
estimated clearance by the Cockcroft-Gault, CKD-EPI or Hoek formula.

*different from eCL $\mathrm{CG}_{\mathrm{CG}}$ and $\mathrm{eCL}_{\mathrm{CKD}-\mathrm{EPI}}(\mathrm{p}<0.01)$.

** different from eCL $\mathrm{L}_{\text {CKD-EPI }}(\mathrm{p}<0.05)$.

*** different from eCL $\mathrm{CLK}_{\text {CKDII }}$ and $\mathrm{eCL}_{\text {Hoek }}(\mathrm{p}<0.01)$.

were unreliable (cystatin $\mathrm{C}$ was not determined). Villa and colleagues compared the reciprocals of plasma cystatin $\mathrm{C}$ and creatinine with $24 \mathrm{~h}-\mathrm{CL}_{\mathrm{CR}}$ in 50 critically ill patients at risk for developing acute renal failure, and reported a much stronger correlation for $1 /$ cystatin $C$ than for $1 /$ creatinine [24]. Recently, Delanaye and colleagues reported data from a study in 47 critically ill patients, in which a true gold standard, iohexol clearance, was used [25]. Cystatin $C$ was superior to creatinine to detect patients with GFR $<60 \mathrm{~mL} / \mathrm{min}$, but patients with a plasma creatinine concentration $>1.5 \mathrm{mg} / \mathrm{dL}$ were excluded from the study. In general, our results agree with these previous findings, but significantly extend the body of evidence in a large cohort $(n=100)$ of unselected (with regard to renal function) ICU patients.

Of concern is the lack of agreement of any of the three formulae with high $\mathrm{CL}_{\mathrm{CR}}$-values, and their low sensitivity to detect patients with augmented renal clearance $\left(\mathrm{CL}_{\mathrm{CR}}>\right.$ $130 \mathrm{~mL} / \mathrm{min} / 1.73 \mathrm{~m}^{2}$ ), who are at risk for inappropriately low drug concentrations, e.g. of antibiotics. This again calls to mind that none of the formulae was designed for critically ill patients, but rather for detection and followup of chronic renal disease. When augmented renal clearance is suspected, it seems advisable to rely on the endogenous creatinine clearance rather than on estimates.

Several limitations must be mentioned. Our data were extracted as a secondary analysis from pharmacokinetic studies on renally eliminated antibiotic agents. Reliable quantification of renal function was therefore an important feature of the study designs, but some aspects were neglected, which would be necessary for a more thorough assessment of renal function parameters in critically ill patients. For one, renal function in critically ill patients is certainly dynamic. Glomerular filtration (as only the most important part of "renal function" in the context of drug dosing) can rapidly change due to e.g. hemodynamic alterations or systemic inflammation, two common events in ICU patients. Patients' conditions

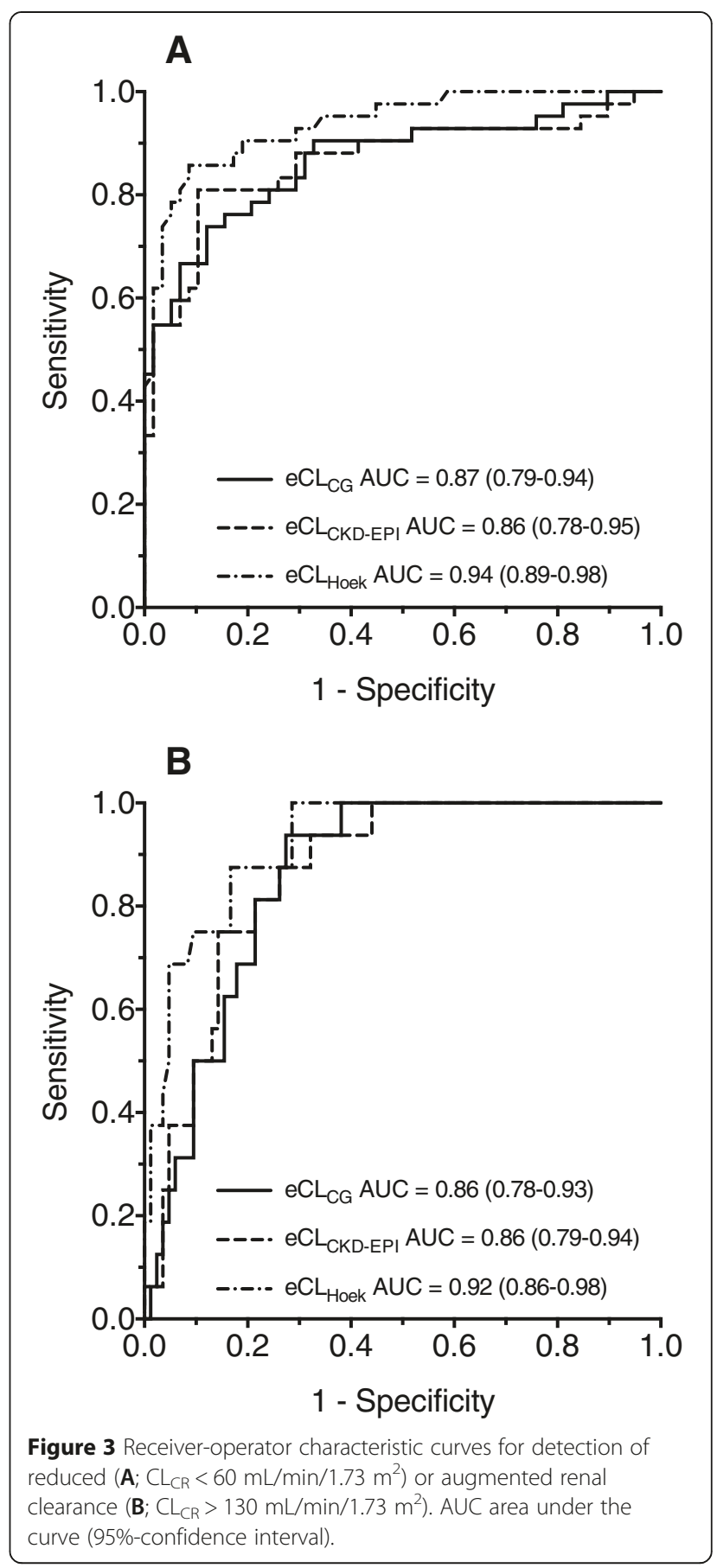

were clinically judged to be "stable", but more formal criteria (e.g. for vasopressor doses, fluid balance or urine output) would have been preferable. Second, the length of the urine collection periods were quite variable between patients, being only $\sim 2$ hours in some cases. Although such short periods have been reported to adequately substitute longer intervals (24 hours) [26], the results would be easier to interprete if a uniform protocol had been used for all patients, even if our sensitivity analysis did not show an 
influence of the duration of urine collection. Finally, endogenous creatinine clearance is also only an approximation of glomerular filtration. Besides free glomerular filtration, it is also subject to tubular secretion which becomes quantitatively more important when GFR decreases [27]. Tubular secretion of creatinine may be differentially affected by chronic or acute renal disease, and can be inhibited by a number of drugs (e.g. trimethoprim and cimetidine), which leads to a lower endogenous creatinine clearance despite constant GFR [27]. (In fact, blocking tubular secretion of creatinine by coadministration of cimetidine has been suggested as a mean to improve the accuracy of endogenous creatinine clearance measurements [28].) Cimetidine is not in use in the participating ICUs, and sulfamethoxazole-trimethoprim is administered only rarely (for prevention or treatment of Pneumocystis jirovecii infections); the prevalence of specific chronic disease (e.g. glomerulonephritis) was certainly minimal in our population of surgical ICU patients, whereas both degenerative loss of renal function and acute kidney injury probably accounted for the large part of patients with reduced $\mathrm{CL}_{\mathrm{CR}}$. Unfortunately, however, a more detailed analysis is not possible because these informations were not systematically recorded. The use of a true gold standard, i.e. clearance of an exogenous marker such as inulin or iothalamate, would certainly have been desirable, but is unlikely to be done in clinical routine or on a large scale in clinical studies. As a compromise of validity and practicability, the use of endogenous creatinine clearance as reference, as done in the present study, seems therefore justified.

\section{Conclusions}

We assessed the agreement of the Cockcroft-Gault formula, the CKD-EPI formula (both based on plasma creatinine) and the Hoek formula (based on cystatin C) with measured creatinine clearance in a comparatively large and unselected cohort of surgical ICU patients. In accordance with previous findings, extreme values of creatinine clearance were observed in patients with plasma creatinine concentrations below the upper reference limit. The Hoek formula was significantly more precise than the other two formulae. The value of cystatin $C$ for clinical decision making and to guide drug dosing in ICU patients should be further defined (e.g. by inclusion in pharmacokinetic studies), before it may find a role in clinical routine. However, identification and quantification of augmented renal clearance without urine collection remains problematic.

\section{Additional files}

Additional file 1: Anonymised clinical data and renal function estimates of the 100 study participants.

Additional file 2: Separate analysis of subsets stratified for the duration of urine collection.
Competing interests

The authors declare that they have no competing interests.

\section{Authors' contributions}

TS, SM and SB were responsible for patient enrolment and data acquisition of study 2, and were involved in drafting and critically revising the manuscript. CG determined the plasma and urine concentrations of creatinine and the plasma concentrations of cystatin C, was involved in data analysis and interpretation, and in drafting and critically revising the manuscript. MGK designed and conducted both studies, was responsible for data analysis and interpretation, and wrote the manuscript. All authors read and approved the final manuscript.

\section{Acknowledgements}

We are indebted to Mrs Annett Christel, study nurse at the study centre Halle, for her excellent work. This work was supported by institutional sources only.

\section{Author details}

'Department of Anaesthesiology and Surgical Intensive Care, University Hospital of Halle (Saale), Ernst-Grube-Str. 40, 06120 Halle (Saale), Germany. ${ }^{2}$ Department of Anesthesiology, University Hospital Hamburg-Eppendorf, Martini-Str. 52, 20246 Hamburg, Germany. ${ }^{3}$ Institute for Clinical Chemistry and Laboratory Medicine, Regensburg University Medical Center,

Franz-Josef-Strauß-Allee 11, 93053 Regensburg, Germany. ${ }^{4}$ Department of Anesthesiology and Intensive Care, Charité Universitätsmedizin Berlin Campus Benjamin Franklin, Hindenburgdamm 30, 12200 Berlin, Germany. ${ }^{5}$ Department of Clinical Pharmacy and Biochemistry, Institute of Pharmacy, Freie Universitaet Berlin, Kelchstr. 31, 12169 Berlin, Germany.

Received: 8 January 2015 Accepted: 21 April 2015

Published online: 28 April 2015

\section{References}

1. Brochard L, Abroug F, Brenner M, Broccard AF, Danner RL, Ferrer M, et al. An Official ATS/ERS/ESICM/SCCM/SRLF Statement: Prevention and Management of Acute Renal Failure in the ICU Patient: An International Consensus Conference in Intensive Care Medicine. Am J Respir Crit Care Med. 2010;181:1128-55.

2. Kashani K, Al-Khafaji A, Ardiles T, Artigas A, Bagshaw SM, Bell M, et al. Discovery and validation of cell cycle arrest biomarkers in human acute kidney injury. Crit Care. 2013;17:R25.

3. Bihorac A, Chawla LS, Shaw AD, Al-Khafaji A, Davison DL, Demuth GE, et al. Validation of cell-cycle arrest biomarkers for acute kidney injury using clinical adjudication. Am J Respir Crit Care Med. 2014;189:932-9.

4. Roberts JA, Abdul-Aziz MH, Lipman J, Mouton JW, Vinks AA, Felton TW et al. Individualised antibiotic dosing for patients who are critically ill: challenges and potential solutions. Lancet Infect Dis. 2014;14:498-509.

5. Udy AA, Roberts JA, Boots RJ, Paterson DL, Lipman J. Augmented renal clearance: implications for antibacterial dosing in the critically ill. Clin Pharmacokinet. 2010;49:1-16.

6. Udy AAB, Baptista JP, Lim NLM, Joynt GMM, Jarrett PD, Wockner L, et al. Augmented Renal Clearance in the ICU: Results of a Multicenter Observational Study of Renal Function in Critically III Patients With Normal Plasma Creatinine Concentrations*. Crit Care Med March 2014. 2014;:42:520-7.

7. Cockcroft DW, Gault MH. Prediction of creatinine clearance from serum creatinine. Nephron. 1976;16:31-41.

8. Baptista JP, Udy AA, Sousa E, Pimentel J, Wang L, Roberts JA, et al. A comparison of estimates of glomerular filtration in critically ill patients with augmented renal clearance. Crit Care. 2011;15:R139.

9. Baptista JP, Neves M, Rodrigues L, Teixeira L, Pinho J, Pimentel J. Accuracy of the estimation of glomerular filtration rate within a population of critically ill patients. J Nephrol. 2014;27:403-10.

10. Lipcsey M, Furebring M, Rubertsson S, Larsson A. Significant differences when using creatinine, modification of diet in renal disease, or cystatin C for estimating glomerular filtration rate in ICU patients. Ups J Med Sci. 2011;116:39-46.

11. Hoste EAJ, Damen J, Vanholder RC, Lameire NH, Delanghe JR, Van den Hauwe K, et al. Assessment of renal function in recently admitted critically ill patients with normal serum creatinine. Nephrol Dial Transpl. 2005;20:747-53. 
12. Séronie-Vivien S, Delanaye P, Piéroni L, Mariat C, Froissart M, Cristol J-P. Cystatin C: current position and future prospects. Clin Chem Lab Med. 2008;46:1664-86.

13. KDIGO. Clinical Practice Guideline for the Evaluation and Management of Chronic Kidney Disease. Kidney Int Suppl. 2013;3:1-150.

14. Levey AS, Stevens LA, Schmid CH, Lucy ZY, Castro AF, Feldman HI, et al. A New Equation to Estimate Glomerular Filtration Rate. Ann Intern Med. 2009;150:604-12

15. Hoek FJ, Kemperman FAW, Krediet RT. A comparison between cystatin C, plasma creatinine and the Cockcroft and Gault formula for the estimation of glomerular filtration rate. Nephrol Dial Transpl. 2003;18:2024-31.

16. Kees MG, Hilpert JW, Gnewuch C, Kees F, Voegeler S. Clearance of vancomycin during continuous infusion in Intensive Care Unit patients: correlation with measured and estimated creatinine clearance and serum cystatin C. Int J Antimicrob Agents. 2010;36:545-8.

17. Minichmayr IK, Steinke T, Moritz S, Beck S, Kees F, Kees MG, et al. A-715: Determinants of Meropenem Clearance in ICU Patients Receiving Continuous Infusion: Value of Cystatin C. Interscience Conference on Antimicrobial Agents and Chemotherapy (ICAAC). Washington, DC: American Society for Microbiology; 2014.

18. Dubois D, Dubois EF. A formula to estimate the approximate surface area if height and weight be known. Arch Intern Med. 1916;17:863-71.

19. Hermida J, Tutor JC. Serum cystatin C for the prediction of glomerular filtration rate with regard to the dose adjustment of amikacin, gentamicin, tobramycin, and vancomycin. Ther Drug Monit. 2006;28:326-31.

20. Chin PKL, Chew-Harris JSC, Florkowski CM, Begg EJ. The performance of contemporary cystatin C-based GFR equations in predicting gentamicin clearance: GFR equations using cystatin C for gentamicin clearance. Br J Clin Pharmacol. 2015;79:268-77.

21. Frazee EN, Rule AD, Herrmann SM, Kashani KB, Leung N, Virk A, et al. Serum cystatin $C$ predicts vancomycin trough levels better than serum creatinine in hospitalized patients: a cohort study. Crit Care. 2014;18:R1 10.

22. Hudson JQ, Nolin TD. Estimated GFR and Cystatin C for Drug Dosing: Moving Beyond Proof of Concept to Clinical Translation? Am J Kidney Dis. 2015;65:534-6.

23. Knight EL, Verhave JC, Spiegelman D, Hillege HL, Zeeuw DD, Curhan GC, et al. Factors influencing serum cystatin $C$ levels other than renal function and the impact on renal function measurement. Kidney Int. 2004;65:1416-21.

24. Villa P, Jimenez M, Soriano M-C, Manzanares J, Casasnovas P. Serum cystatin C concentration as a marker of acute renal dysfunction in critically ill patients. Crit Care. 2005;9:R139-43.

25. Delanaye P, Cavalier E, Morel J, Mehdi M, Maillard N, Claisse G, et al. Detection of decreased glomerular filtration rate in intensive care units: serum cystatin C versus serum creatinine. BMC Nephrol. 2014;15:9.

26. Herrera-Gutiérrez M, Seller-Pérez G, Banderas-Bravo E, Muñoz-Bono J, Lebrón-Gallardo M, Fernandez-Ortega J. Replacement of 24-h creatinine clearance by $2-h$ creatinine clearance in intensive care unit patients: a single-center study. Intensive Care Med. 2007;33:1900-6.

27. Andreev E, Koopman M, Arisz L. A rise in plasma creatinine that is not a sign of renal failure: which drugs can be responsible? J Intern Med. 1999;246:247-52.

28. Roubenoff R, Drew H, Moyer M, Petri M, Whiting-O'Keefe Q, Hellmann DB. Oral Cimetidine Improves the Accuracy and Precision of Creatinine Clearance in Lupus Nephritis. Ann Intern Med. 1990;113:501-6.

\section{Submit your next manuscript to BioMed Central and take full advantage of:}

- Convenient online submission

- Thorough peer review

- No space constraints or color figure charges

- Immediate publication on acceptance

- Inclusion in PubMed, CAS, Scopus and Google Scholar

- Research which is freely available for redistribution 